\title{
„ОБЩ ЯЗИК С ВИРАЖЕНИЕ НАРОДНО“. ЕЗИКОВИТЕ НОРМИ В ПРЕВОДА НА А. ГРАНИТСКИ ,ЗА ТРЫГОВСКО ПИСМОПИСАНЇЕ“, 1858 Г. (С ОГЛЕД НА ПРИЛАГАТЕЛНИТЕ И ЧИСЛИТЕЛНИТЕ ИМЕНА, МЕСТОИМЕНИЯТА И ГЛАГОЛИТЕ)
}

НАДКА НИКОЛОВА

ШУМЕНСКИ УНИВЕРСИТЕТ „ЕПИСКОП КОНСТАНТИН ПРЕСЛАВСКИ“ nikolova55@gmail.com

В статията са представени резултатите от проучването върху приноса на Анастас Гранитски за изграждането на структурната основа и езиковите норми на българския книжовен език от епохата на Възраждането. Обект на наблюдение е част от превода на „Тръговско ржководство“ (1858), озаглавена „За тръговско писмописанїе“. Предмет на интерпретация са прилагателните и числителните имена, местоименията и глаголите. Анализът сочи, че е прокарана категорична линия на сближаване на писмената реч с говоримата. Проследява се търсенето от страна на преводача на онези по-широко разпространени езикови средства, които да направят писмената реч съвременна и универсална - част от процеса на създаване на новобългарската книжовна езикова норма.

Ключови думи: Българско възраждане, новобългарски книжовен език, епистоларен стил, езиково-правописни норми

\section{ОБЩ ЯЗИК С ВИРАЖЕНИЕ НАРОДНО. THЕ LANGUAGE NORMS IN THE Translation OF A. GRANITSKI's $3 A$ TPЪГОВCKO ПИСМОПИСАНÏ̈ (ON COMMERCIAL LETTER WRITING), 1858 (With a View to Adjectives, Numerals, Pronouns and Verbs)}

NADKA NiKOLOVA UNIVERSITY OF SHUMEN “EPISKOP KONSTANTIN PRESLAVSKI”
nikolova55@gmail.com

The article presents the results of a study on the contribution of Anastas Granitski to building the structural basis and spelling and language norms of the Bulgarian literary language of the Revival period. The subject of observation is a part of the translation of the 1858 Тръговско ржководство (Commercial Guidebook) titled За тръговско писмописанї (On Commercial Letter Writing), a practical guide for keeping business correspondence. The author studies adjectives, numerals, pronouns and verbs. The analysis leads to the conclusion that the text reveals significant convergence of written and spoken language. The author traces the translator's efforts to adopt widely-used 
linguistic means that would make the language of his work modern and universal - a part of the process of establishing a new Bulgarian language norm.

Keywords: Bulgarian Revival, modern Bulgarian literary language, epistolary style, linguistic and spelling norms

В литературата, посветена на предприемачеството през Възраждането, особено място заема преводът на български на един енциклопедичен учебник по търговия на известния автор и богат търговец Константинос Мелас. Преводът е направен от Анастас Гранитски и е публикуван през 1858, а неговото заглавие на български е „Тръговско ръководство“.

От досегашни наблюдения върху биографията и дейността на Ан. Гранитски и конкретно върху този превод (подробно вж. Николова/Nikolova 2020; 2021a; 2021б) може да се направи извод, че преводачът се придържа към едно средно, умерено схващане във вижданията си за езиковия идиом, а именно, че той трябва да се опира както на високия стил и рамките, които предпоставя езиковата традиция, така и на говоримия български език. А граматиките, които е приел за неоспорим авторитет, са две: „Болгарска граматика“ от Неофит Рилски (1835) и „Първичка българска граматика“ от Иван Богоров (1844).

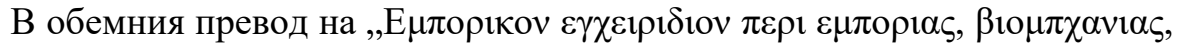

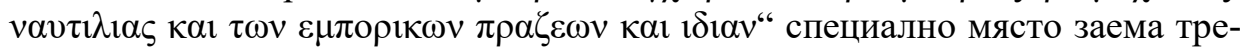
та глава на четвъртата част със заглавие ,За тръговско писмописан1е“. В нея авторът К. Мелас представя видовете делови писма, типични за търговското съсловие. Преводът на Гранитски предполага, че българските търговци са ги използвали като основа за собствената си делова кореспонденция. Респектирани от авторитета на автора на гръцкия оригинал, който е копирал френски образци, и на Ан. Гранитски, който през 50-те години на 19. век вече е наложил името си на отличен познавач на гръцкия и френския език, българските търговци, без съмнение, са следвали съветите, дадени в тази глава. Текстьт е повлиял върху търговската кореспонденция на българите не само с препоръките за нейното създаване и с подбора на езикови средства за професионален изказ, с терминологията и техническото си оформление, но и с правописно-езиковите си особености. По всяка вероятност популяризирането на езика на превода в деловата кореспонденция на една уважавана и влиятелна част от българското общество предприемачите и търговците - е допринесло както за формирането на административно-деловия стил от третата четвърт на 19. век, така и за унифицирането на езиковите норми на изграждащия се новобългарски книжовен език.

Настоящият текст е съсредоточен върху прилагателните и числителните имена, местоименията и глаголите.

\section{Прилагателни имена}

Традиционно прилагателните се описват с формите им за именителен и за косвен падеж. Окончанията им се представят в следната таблица. 


\begin{tabular}{|c|c|c|c|c|}
\hline \multirow[t]{2}{*}{$\begin{array}{l}\text { Род и } \\
\text { число }\end{array}$} & \multicolumn{2}{|c|}{$\begin{array}{c}\text { Форми за именителен } \\
\text { падеж }\end{array}$} & \multicolumn{2}{|c|}{ Форми за косвен падеж } \\
\hline & $\begin{array}{c}\text { Нечленувани } \\
\text { форми }\end{array}$ & $\begin{array}{c}\text { Членувани } \\
\text { форми }\end{array}$ & $\begin{array}{c}\text { Нечленувани } \\
\text { форми }\end{array}$ & $\begin{array}{c}\text { Членувани } \\
\text { форми }\end{array}$ \\
\hline М.р. ед.ч. & $-\varnothing /-b i \check{u}$ & $-b i \check{u}$ & $-\varnothing /-b u \check{u}$ & $-b i \check{u}$ \\
\hline Ж.р. ед.ч & $-a$ & $-m a$ & $-\AA$ & $-m \AA$ \\
\hline Ср.р. ед.ч & $-O$ & $-m o$ & $-O$ & $-m a$ \\
\hline Мн.ч. & $-u$ & $-m u$ & $-b l /-u$ & $-m b l$ \\
\hline
\end{tabular}

\section{1. Нечленувани форми на прилагателните имена}

1.1. Прилагателните от мъжки род в именителен падеж имат нулево окончание в единствено число, напр.: най-неприличенъ начинъ е оный (692) или щее бжде по-точенъ (692). Същите са формите и за косвен падеж - напр.: съ особенъ начинъ (692), съ благоразуменъ отговорь (693). Появяват се, макар и рядко, и имена с дълго окончание - прилагася обыкновенно параграфь поржчителный (рекоммандателный) (694), тоя потргбный отговорь е нуженъ (684).

1.2. Подобно на съществителните имена от женски род, прилагателните в женски род разграничават форми за именителен и косвен падеж в единствено число. За това свидетелстват примери като следните: за именителен падеж - тан мгока... е обаче неприлична (695), главна основа тргбва за искренность (695); за косвен падеж - сь благоразумнж студенинж (692), за способность-тж управителевж (684), имж недобрж честь (684), за знаменитж повредж (687).

1.3. Пряката и косвената падежна форма на прилагателните имена в среден род е една и съща в единствено число, напр.: пргопоржчително писмо е онова... (694), това заведенїе е достойно (684) - за именителен падеж, и съ повторително удостовгренїе (692), подъ законоположително принужденїе (693) - за косвен. Интересна е формата в израза въ бжджщее вргми (692), в която окончанието е дълго.

1.4. Има тенденция формите на нечленуваните прилагателни имена в множествено число да се разграничават по отношение на синтактичната си служба. В повечето случаи в именителен падеж окончанието се записва с буква $\boldsymbol{u}$, напр.: уверителни писма (загл., 693), не сқ никакъ тръгователни (693), най-знаменити окржжни писма сл онїя (677). В косвен окончанието е -bl, напр.: тргбва да съдрьжмва изясненїн приличны (692); да нослть... въ действителны монеты нуждны-ты си разноскы (693), но и -и за безмгстни празднословї (678), сльдъ нгколко учтиви ргъчь (679), колко-то и гольви капитали и да бы ималь (682).

\section{2. Членувани форми на прилагателните имена}

2.1. Най-същественото при членуваните прилагателни имена в мъжки род единствено число - както в пряк, така и в косвен падеж - е, че пълното старо окончание функционира като определителен член. Доказват го при- 
мерите: за именителен падеж - Почтенный тръговецъ... ще отговори (683), Случнйный запись... е кога-то (697), за косвен падеж - на оправдаемый доста е да наумимь (692), спорядь истый начинь (684), за пргооржчаемый (695).

2.2. Отново подобно на членуваните съществителни от женски род, членуваните форми на прилагателните в женски род единствено число се разграничават падежно. Членната форма за именителен падеж е -ma, напр.: упознато-то благоразумїе и строга-та почтеност сж... (682), безрасждна-та дерзост или безмгрна-та страхливодть ... могжть да даджmь (682). Съответно член -тж е за косвен падеж, напр.: на испращаемљтж стокћ (685), въ уверителнћ-тћ странћ (685), да опише издаденћ-тћ камбиалж (685).

2.3. Членуваните прилагателни имена в среден род имат обща форма за единствено число във всички синтактични служби. Това се доказва от следните примери: за именителен падеж - оправдателно-то писмо тргбва да съдрьжмва (692); Тръговско-то убо писмописанїе е... (675); за косвен падеж - за случено-то сгрешенїе (692), въ мжмрително-то писмо (693).

2.4. В повечето случаи при членуваните прилагателни в множествено число се различава пряк от косвен падеж. Членната форма за именителен падеж е -ти, напр.: за да познавать другь-ти тръговскь заведенїл (694), умножсяватьсл тръговскь-ти сношенї (675). Косвеният падеж се маркира с членна форма -mbl, напр.: успьхъ на тръговскиы-ты интересы (675), за окржжны-ты писма (680). Често обаче двете форми се смесват, напр.: Гольми-ти Банкерскь заведенїн издавать (имен. п.) (693).

От примерите е видно и че причастията, функциониращи като определения - напр. пргопржчнемый (695), испращуаема (685), съдражнемо (686), имат същите адективни окончания.

3. Прилагателните имена се степенуват така, както се степенува и днес, напр.: щзе бжде по-точенъ (692), по-богати рудници (273), по-гольма-та чмсть (219), най-приличный рждь (679), най-голюмљ-тк члсть (268), найпотргбнж рудж (270). Аналитично, с частиците по и най, свързани с дефис, се степенуват и наречията.

\section{Числителни имена}

Формите на редните числителни имена, както и на бройното един повтарят формите на прилагателните и по тази причина тук не се разглеждат. При бройните числителни имена по-особени са членуваните форми за множествено число, напр.: шесть тъхъ мъьсяци (690) ${ }^{3}$, от които се вижда, че числителното е в косвен падеж.

Прави впечатление честата употреба на един в значение на неопределителен член или на неопределително местоимение ('някой/някакъв' или 'кой/какъв да е'), напр.: единъ тръговещъ (675), съ едно внимателно прочитанїе (675), единь благочиненъ писмовень рядъ (676), на единъ корреспонденть (677), наставленїн, кои-то единъ писмописеиъ (677), разидванїе 
на еднк компанїц (677), има едно гольмо влїннїе врьху трьговскь-тьл сношенїя (681) и мн. др. Такива употреби убедително показват нереалността на решението на някои книжовници от разглеждания възрожденски период да се игнорира определителният член като израз на категорията определеност/неопределеност. Ан. Гранитски не само определя славянското выраженїе (разбирай черковнославянското, т.е. архаичното) като бжлвочъ ${ }^{4}$, но и практически демонстрира осъзнаването на промените, настъпили в говоримия език.

\section{Местоимения}

Следва да се посочи, че в главата „За трьговско писмописанї““ засвидетелстваните местоименни форми не дават представа за пълните прономинални парадигми. Липсата на примерни писма, както и учебно-обяснителният тип повествуване ограничават употребата на всички форми. Тези, които са употребени, пробуждат интерес в няколко аспекта и на първо място следва да се установят съставът, функциите и употребата на личните местоимения.

\begin{tabular}{|c|c|c|c|c|c|}
\hline \multirow{2}{*}{$\begin{array}{c}\text { Лице и } \\
\text { число }\end{array}$} & \multirow{2}{*}{$\begin{array}{c}\text { Имени- } \\
\text { телен } \\
\text { падеж }\end{array}$} & \multicolumn{2}{|c|}{ Винителен падеж } & \multicolumn{2}{|c|}{ Дателен падеж } \\
\hline & & $\begin{array}{l}\text { Пълни } \\
\text { форми }\end{array}$ & Кратки & $\begin{array}{l}\text { Пьлни } \\
\text { форми }\end{array}$ & Кратки \\
\hline 1 л. ед.ч. & $\varnothing$ & $\varnothing$ & $\varnothing$ & $\varnothing$ & $\varnothing$ \\
\hline 2 л. ед.ч. & $\varnothing$ & $\varnothing$ & $\varnothing$ & $\varnothing$ & $\varnothing$ \\
\hline $\begin{array}{c}\text { л. м.р. } \\
\text { ед.ч. }\end{array}$ & $\mathrm{OHb}$ & него & 20 & $\varnothing$ & My \\
\hline $\begin{array}{c}\text { л. ж.р. } \\
\text { ед.ч. }\end{array}$ & $\varnothing$ & нецк & $L K$ & $\varnothing$ & $\varnothing$ \\
\hline $\begin{array}{c}\text { л. ср.p. } \\
\text { ед.ч. }\end{array}$ & mo & $\varnothing$ & $\varnothing$ & $\varnothing$ & $\varnothing$ \\
\hline 1 мн.ч. & $\varnothing$ & $\mathrm{Hacb}$ & $H u$ & намь & $\varnothing$ \\
\hline 2 мн.ч. & $\varnothing$ & $\varnothing$ & $\varnothing$ & $\varnothing$ & $\varnothing$ \\
\hline 3 мн.ч. & $m \ddot{u} u$ & $m r b x b$ & $2 b l$ & $\varnothing$ & $u M b$ \\
\hline
\end{tabular}

От именителните форми на личните местоимения са употребени само три третолични: две за единствено - онъ $(687,688)$ и то $(675)$, и едно за множествено число - тӥи (679). След като за избора на онъ преводачът няма причини от териториален характер (и родното му място, и пребиваването му впоследствие - най-вече Шумен и Търново - предполагат източнобългарското той), единственото обяснение е, че е отдал предпочитание на черковнославянския вариант. Изборът му обаче е с несистемен характер, тъй като е единствен на фона на останалите варианти от източен тип. Освен това местоимението за среден род функционира като показателно mо писмописанїе (675) - нещо, характерно за източния диалектен тип. От 
винителните местоимения са налични само пълните форми него и нељк за единствено и насъ и тъхъ за множествено число, както и кратките го, нu, гы. Това, което е най-характерно за дателните местоимения за 3 л., е, че липсват пълни форми освен една - намъ (691). От кратките са представени само му (679) и имъ (677). Видно е, че не може да се правят изводи за цялостния облик на парадигмата на личните местоимения.

Притежателните местоимения се срещат рядко, а съставът им е също ограничен.

\begin{tabular}{|c|c|c|c|}
\hline $\begin{array}{c}\text { Лице и } \\
\text { число }\end{array}$ & $\begin{array}{c}\text { Именителен падеж - } \\
\text { пьлни форми }\end{array}$ & $\begin{array}{c}\text { Косвен падеж - } \\
\text { пълни форми }\end{array}$ & Кратки \\
\hline 1 л. ед.ч. & $\varnothing$ & $\varnothing$ & $\varnothing$ \\
\hline 2 л. ед.ч. & $\varnothing$ & $\varnothing$ & $\varnothing$ \\
\hline $\begin{array}{l}3 \text { л. м.р. } \\
\text { ед.ч. }\end{array}$ & негова, негово & $\varnothing$ & My \\
\hline $\begin{array}{c}3 \text { л. ж.р. } \\
\text { ед.ч. }\end{array}$ & нейно & нейнж & $\grave{u}^{5}$ \\
\hline 1 Л. МН.Ч. & нашь; наши & нашему, нашж; нашы & $H u$ \\
\hline 2 Л. Мн.ч. & $\varnothing$ & $\varnothing$ & $\varnothing$ \\
\hline 3 Л. Мн.ч. & $\varnothing$ & $\varnothing$ & $u M b$ \\
\hline
\end{tabular}

От пълните притежателни местоимения интерес представляват примерите с дателен падеж в мъжки род - нашему корреспонденту (687), нашему заемателю (688), и с винителен в женски род - за неговж (687). При мъжки род формите за косвен падеж са общи с именителните: на нашь корреспонденть (688). Пълните форми се членуват по същия начин, както прилагателните имена, напр.: за нашїй дльгъ (688), на нашїй корреспондентъ (691). При това в мн.ч. се различават именителните от косвените форми, напр. наши-ти... тръговции труднтсл (676) срещу косвената да свьршваме нашы-ты сношенїя (691). Разграничаването е в сила и при формите за женски род, които приемат окончание -љ, напр.: за нейнљ-тљ (682), безъ... нашк (684).

Може да се твърди, че много по-честотни са кратките притежателни местоимения, чиято форма и употреба е както в съвременния български

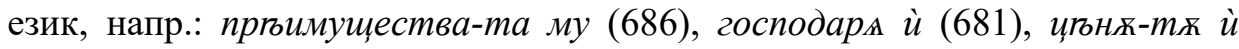
(682), матерный имъ языкъ (676), съчиненїе-то имъ (680).

Редовна е употребата на възвратните местоимения - лични и притежателни. Техните форми и употребата им са както съвременните, напр.: себе си (679); свое-то (679), за свои-ты (678), корреспонденты-ты си (676). И при тях са налице дателни форми - своему корреспонденту (686).

Малко са въпросителните и образуваните от тях неопределителни и отрицателни местоимения. Макар и пълната им парадигма да не е възстановима, може да се обобщи, че не са много по-различни като състав и 
употреба от съвременните. От въпросителните местоимения място в тази част от „Тръговско ръководство“ имат какъвъ (678) и колко (694). Семантиката на что отделя местоимението от въпросителните прономинализатори, тъй като то само по форма е такова. В двата примера: всичко что казахме (680) и знанїн, что имжть управители-ти (678), е видно, че что има значение на относителното местоимение което/които.

Употребата на въпросителни вместо относителни местоимения е характерна разговорна черта през Възраждането и замяната им с относителни е белег за интелектуализацията на езика. В сравнение с останалите славянски езици те са особен прономинален клас, развили са се сравнително късно и имат специфична употреба. Функционирането им като съюзна дума в постпозитивни подчинени изречения (най-често определителни) е маркер за книжовна обработка в речта на възрожденските книжовници и винаги се е коментирало при определяне на нормите, които са характеризирали текстовете им. Те изобилстват в превода на Гранитски, напр.: който употргбльва (675), тръговецъ-ть, за кого-то (683), камбїллж ком-то ще см заплати (688), оть кољћ-то (679), кое-то (677), кои-то (675); когаmо (677), гдъ-то (680), колко-то (682). Употребата им е белег за интелектуализация на книжовния език и допринася за специализацията на научния стил.

Добре представени са и неопределителните местоимения, тъй като обяснението за видовете писма е за примерни, неопределени и неконкретни ситуации и кореспонденти. Тези местоимения често се конкурират с числителното един. И тук, както при относителните местоимения, се спазват падежните разлики, макар и да се промъкват именителни вместо очакваните косвени форми, напр.: корреспондентъ-тъ... тргбва да похвалдва нгкой (686). Така за референти съществителни Гранитски употребява нгкой съдружникъ (677), сргщуо нъкого (694); на нъкоцк стокк (680) (за ж.р. присъстват само косвени форми), нъкое заведенїе (677); нъкои (688). За неопределен предмет се използват нъчто (680) и нъчта (676). За референти прилагателни и наречия в текста присъстват местоименията никакво (683) и нъколко (679). Записването на нечто (689) с е вм. с г издава произношението на етимологичната ятова гласна като [е] пред сричка, съдържаща [ш]. Правописни „грешки“ като тази бележат формирането на условията за преглас, наложили се постепенно като книжовни.

Отрицателните местоимения са представени само с няколко форми в преведената част. Те не се различават от книжовните форми днес, като изключим тези за пряк и косвен падеж при местоименията за ж.р.: безъ никокк нашк ответственость (684), не взема никаквж... (684), никакво неугожденїе (690).

Аналогични по граматическите си форми са и обобщителните местоимения: всъкой да приказва (676), но и кратката вспьъ неговъ корреспонденть (677), всякому корреспонденту (690); да ся забглгъжва всяка (688), 
съ всткж (682), но и ще заборави вснка зависть (683), където не се появява очакваното винително окончание: встько нгчто (680); всичкь--ты работы (675), но и за вcbl-mы пунктове (684). Има и две за референти прилагателно и наречие: всжкакъвъ (675) и всжкога (681).

Разграничението между пряк от косвен падеж е налице и при показателните местоимения. Отчетливо се разграничават показателни местоимения за близки от тези за далечни предмети и признаци. Така например от местоименията за близки предмети и признаци място намират в текста тоя е... (679), на тогова (694), таж книга служи (677), за тжьк убо иягль (677), това писмописанїе (675); тїм познанїя ся придобывать (675), чрезь mыл писма (677). Местоименията наречия са две: тука (679) и така (680). За референти прилагателни преводачьт използва такъвъ (678), но и таковый (682); таково (690) и такво (689), както и такыва (68). Аналогични са формите и на показателните местоимения за далечни предмети и признаци, напр.: оный, кой-то (678), на оногова (676), онова (677), онїи, кої-то (677), на оныцж (689). Вижда се, че Гранитски предпочита само вариантите без форманта -зи.

\section{Глаголи}

По отношение на глаголните форми, употребени в частта „За тръговско писмописанї““ (съответно в „Тръговско рљководство“, от която писмовникът е част), на първо място е необходимо да се коментира употребата на един или друг тип окончания за формите в сегашно време на глаголи от I и II спрежение. По-точно казано, става дума за характера на крайната съгласна от глаголната основа, която може да е твърда или мека, от една страна, и за писменото означаване на окончанието, което варира в диалектите. Най-разпространени в този период са окончанията, в които старата носовка е наследена от вокалите [ъ] или [а]. Поради характера на превода в тази част се срещат форми само за 3. л. ед.ч. и 3 л. мн.ч. ${ }^{6}$, както и за 1 л. мн.ч.

Би следвало да се очаква, че котленският изговор на глаголите с вокална основа в 3 л. ед.ч. е -й, какъвто е и изговорът в Шуменско и Търновско, където Гранитски пребивава дълги години. В превода на ръководството обаче тези глаголи имат облика от примерите разумъе (675), знае (680), какъвто се препоръчва в Богоровата граматика.

Глаголите от II спрежение в 3 л. мн.ч. в сегашно време имат основа, завършваща на мек консонант, напр.: труднтся (675), сл приносять (679), просвтьтыть (680), сл породжть (683). Образец за избора на буквата ж от Гранитски несъмнено е „Пжрвичка бжлгарска грамматика“ от И. Богоров. Граматиката е образец и за последователното записване на глаголите от I спр. с твърда консонантна основа с ж: сл избггнжть (679), даджть (678), не сл продаджть (680), желањкть (680), пишжть (680). Последният пример, който не е единствен, нарушава приетото от него правило след ж, ч, $u$ да се пише буква, означаваща мекостта им ${ }^{7}$. 
Чрез формите за 1. л. мн.ч. преводачът се присъединява към читателите си, с които фиктивно извършва общи действия. Формите на глаголите от I и II спрежение окончават на -м: направимь (679), сл извгстимь (682), платимь (687). Отрицателната форма на имам е не имаме (689). Като се прибави и това, че никъде не се срещна окончание -ме при глаголи от I и от II спрежение за 1. л. мн.ч., би могло да се обобщи, че глаголната парадигма е аналогична на съвременната норма. Несъмнено за формирането и утвърждаването ѝ принос има и твърде разпространеният превод на „Тръговско рдководство“.

От формите за бъдеще време има само една форма за 1. л. ед.ч., а за 2. л. ед.ч. липсват. Примерите показват, че Гранитски си служи със спрегаемия глагол щз, който е използван последователно:

- $\quad$ за 1 л. ед.ч. - щзљ получьк (690);

- $\quad$ за 3 л. ед.ч. - ще бжде (681), ще ся реши (681), не ще прибггне (690); една е само формата, включваща частицата да-щуе да даде (683);

- $\quad$ за 1 л. мн.ч. - щемь приложимь (677) и щзем почювствова (695);

- $\quad$ за 2 л. мн.ч. - щете благоизволите (690) и щзете направите (690); и двата глагола са употребени в готова епистоларна формулировка вм. в ед.ч. като учтиви форми;

- $\quad$ за 3 л. мн.ч. - щжтсл почитжть (678), щкть направжть (679),

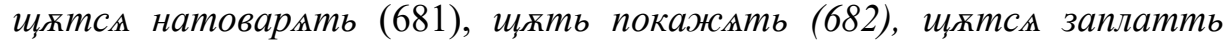
(694).

В превода на „За тръговско писмописанїе“, макар и рядко, се срещат форми и за други глаголни времена, когато това се изисква от съдържанието. Във висока степен те отговарят на съвременната представа за формалното им представяне. Такива са примерите за плусквамперфект - бг писаль (680), и за аорист - казахме (680), който, макар и единствен, издава употреба на авторско „ние“ в повествуването. Повече са примерите за перфект, където също е представено предимно третото лице: не е получиль (676), е прїлль (679), зель е (680), не сл е изврьшило (681), е можло да сл случи (683), не сл е заплатила (688); не сж имали (679), сж сл поискали (684). Скриване на автора зад форми за мн.ч. личи в примера щееь влгьзимь (681). Само една е формата за бъдеще време в миналото: щеше да бжде народно самоубйиство (333).

В писмовника присъстват и две преизказни форми за аорист $-c$ А $и$ здала (685), испратиль (689). Малкото намерени форми убеждават, че преизказването е жива категория, която търси мястото си в епистоларноадминистративния текст, ако може така да се определи упътването за писане на търговски писма.

Ще отбележим и две други форми: е биль зель (694) и сж ся били изображили (675). Определянето им като конклузивни е въз основа на наличието във формите им на спомагателния глагол съм в трето лице, което не е характерно за парадигмата на преизказните форми (Ницолова/Nitsolova 
2008: 352-356). Примерите по-горе илюстрират функционирането на тази глаголна категория в средата на 19. век.

Условното наклонение е представено с три форми: добро бы было (680) и да бы имал (682). В третата форма - ако бы да сл е случило (691)кондиционалното значение се носи изцяло от ако бы да. Примерът е подобен на формите, използвани в „Диплографія“ от Ст. и Хр. Караминкови ако бы че стане нужда, ако бы че купите (127), ако бы че съберемь (138). Това сравнение засилва предположението, че комплексът ако бы че/да е типичен за речта на българите от централнобалканския район.

\section{Изводи}

Анализът на граматичните норми в епистоларната част на превода на Ан. Гранитски свидетелства за еволюция в представата у българските възрожденски книжовници за това как да изглеждат и как да функционират езиковите норми през 50-те години на 19. век. Не трябва да се забравя, че основната дейност на Гранитски, който е със солидно образование по чужди езици (гръцки и френски) и медицина, е била редакторската и учителската, и това несъмнено го е изправяло пред много предизвикателства, за които е търсел решение в преводите си. Преводачеството му се осъществява в преломни и решителни десетилетия за формирането на книжовния ни език, а граматиката, повлияла в най-висока степен върху писмената практика през 40-те и 50-те години на 19. век, когато се отпечатва преводът на „За тръговско писмописан1е“, е „Първичка българска граматика“ на Иван Богоров. Граматичните норми, които се наблюдават в превода на Ан. Гранитски, показват, че тя е се ползвала с много висок авторитет. Това са десетилетията, в които книжовниците осмислят необходимостта от модернизация на писмената реч, от нейното осъвременяване и сближаването ѝ с говоримия език, и търсят онези по-широко разпространени езикови средства, които да я направят универсална - с други думи, стремят се към създаването на новобългарската книжовноезикова норма.

\section{Благодарности}

Изследването е по проект № КП-06-Н40/8 на тема „Писмовниците на Българското възраждане като източник за формирането и функционирането на книжовния език”, финансиран от Фонд „Научни изследвания“ към Министерството на образованието и науката на РБ.

\section{БЕЛЕЖКИ / NOTЕS}

${ }^{1}$ Повече за енциклопедията вж. у Николова (Николова/Nikolova 2021б).

2 За съществителните имена вж. Николова/Nikolova 20216.

3 За формите от този вид вж. подробно у И. Гълъбов (Гълъбов/Galabov 1954).

${ }^{4}$ Вж. подробно у Н. Николова (Николова/Nikolova 2021).

${ }^{5} \mathrm{C}$ диакритичен знак като в съвременния правопис Гранитски записва краткото притежателно местоимение $\grave{u}$ за женски род, което е нещо редовно във възрожденските текстове.

${ }^{6}$ Има само една форма за 1. л. ед.ч., и то за бъдеще време - щзљ получьк (690). 
${ }^{7}$ В „Пжрвичка бжлгарска грамматика“ И. Богоров го пише по същия начин, вж. с. $63,106$.

\section{ЛИТЕРАТУРА}

Гълъбов 1954: Гълъбов, Ив. Пет, петтях, петима, петмина. - Български език, № 3 , с. $250-258$.

Николова 2020: Николова, Н. Преводът на Анастас Гранитски „За тръговско писмописание“ от 1858 г.: уводни бележки. - Български език, № 3, 45-58.

Николова 2021 а: Николова, Н. „Взаимното писание“ - „душата на търговията“ (Правописът на „За тръговско писмописанїе“, 1858 г., от Ан. Гранитски). В: Паисиеви четения. Научни трудове. Пловдив, УИ Паисий Хилендарски, 2020 (под печат).

Николова 2021б: Николова, Н. „Общ язик с виражение народно“. Езиковите норми в превода на А. Гранитски „За тръговско писмописанїе“, 1858 г. (С оглед на съществителните имена). - Български език, № 3, с. 108-119.

Ницолова 2008: Ницолова, Р. Българска граматика. Морфология. София, УИ „Св. Климент Охридски“.

\section{REFERENCES}

Galabov 1954: Galabov, Iv. Pet, pettyah, petima, petmina. - Balgarski ezik, № 3, s. $250-258$.

Nikolova 2020: Nikolova, N. Prevodat na Anastas Granitski „Za tragovsko pismopisanie“" ot 1858 g.: uvodni belezhki. - Balgarski ezik, god. 67, № 3, 45-58.

Nikolova 2021a: Nikolova, N. „Vzaimnoto pisanie“ - „dushata na targoviyata“ (Pravopisat na „Za tragovsko pismopisanie“", 1858 g., ot An. Granitski). - In: Paisievi cheteniya. Nauchni trudove. Plovdiv, UI "Paisiy Hilendarski” (pod pechat).

Nikolova 2021b: Nikolova, $N$. „Obsht yazik s virazhenie narodno“. Ezikovite normi v prevoda na A. Granitski „Za tragovsko pismopisanie“, 1858 g. (S ogled na sashtestvitelnite imena). - Balgarski ezik, N 3, s. 108-119.

Nitsolova 2008: Nitsolova, R. Balgarska gramatika. Morfologiya. Sofia, UI „Sv. Kliment Ohridski“.

$\square$ Проф. д-р Надка Николова

Шуменски университет „Епископ Константин Преславски“

Ул. Университетска № 115, Шумен 9700, България

$\triangle$ Prof. Nadka Nikolova, PhD

University of Shumen "Episkop Konstantin Preslavski"

115 Universitetska №, Shumen 9700, Bulgaria 